\title{
Det moralske grunnlaget for å vurdere samtykkekompetanse
}

\author{
Bjorn Hofmann
}

Hovedregelen for å kunne gi helsehjelp i Norge er at pasienter samtykker. I henhold til pasientrettighetsloven er det helsepersonell som skal avgjøre om pasienter har samtykkekompetanse. Dersom pasienter ikke er samtykkekompetente, kan de behandles mot deres uttrykte ønske. Dette reiser det viktige og vanskelige spørsmålet: På hvilket grunnlag skal helsepersonell vurdere samtykkekompetansen? Det finnes ulike, psykologiske, tester. Disse brukes ikke i Norge, hvor vurderingene i stor grad er basert på skjønn. Denne artikkelen undersøker en del sentrale moralske føringer for hvordan man bør vurdere samtykkekompetanse dersom målsettingen er å respektere personers selvbestemmelse. Samtykkekompetansen bør vurderes uavhengig av hvordan vi vurderer det personen bestemmer seg for, men ikke uavhengig av situasjonen vedkommende er i. Kravene til samtykkekompetanse bør ikke variere med kompleksitet, risiko og nytte av helsetiltak, mens kravene til vurderingens pålitelighet kan variere.

Nøkkelord: beslutningskompetanse, kompetansevurdering, selvbestemmelse, autonomi.

\section{Vurdering av samtykkekompetanse - en forutsetning for helsefaglig behandling}

Selvbestemmelse har i økende grad blitt en verdi og et sentralt moralsk prinsipp i Norge, som i mange vestlige land. Samtykket har i den forbindelse blitt en praktisk måte å forvalte og fremme selvbestemmelsen på, ikke minst innen helsevesenet. Fra helselovsreformen i 1999 og fremover har pasienters selvbestemmelse fått en mer tydelig plass i norsk helselovgiving. 
I forarbeidene til pasientrettighetsloven vises det til at samtykket bygger på at individet har full bestemmelsesrett i forhold til sin frihet, sin helse og sitt liv, uavhengig av dets samfunnsmessige tilknytning og sosial sammenheng (Ot.prp. nr. 12 1998-1999), og pasientrettighetsloven har eksplisitt krav om samtykke (\$4).

Hvem kan samtykke, og hvem skal avgjøre samtykkekompetanse? På disse spørsmålene gir loven klare svar: Ifølge $\$ 4-3$ har myndige personer og personer over 16 år rett til å samtykke til helsehjelp, og det er helsepersonell som avgjør samtykkekompetanse. ${ }^{1}$ Hvordan skal så samtykkekompetanse avgjøres? Her gir loven få føringer ut over at grunnen til redusert samtykkekompetanse kan være «[...] fysiske eller psykiske forstyrrelser, senil demens eller psykisk utviklingshemming slik at pasienten åpenbart ikke er i stand til å forstå hva samtykket omfatter». ${ }^{2}$ Men hva med mennesker som er forvirrede, eller som på enkelte områder har vanskelig for å orientere seg? Hva med rusmiddelbrukere og personer med hukommelsessvikt - hva med pasienter med sterke smerter, eller som av andre grunner har vansker med å bestemme seg, som skifter mening, eller er inkonsistente?

Det er utviklet flere tester for måling av samtykkekompetanse (Appelbaum et al. 2001; Tunzi 2001; Etchells et al. 1996; Moye 1999; Glass 1997; Northoff 2006; Wong et al. 1999; Howe et al. 2003), men flere av disse er kritisert (Ganzini et al. 2003; Schneider et al. 2006; White 1994; Berghmans et al. 2000). Det er ikke etablert noen standard, og tester for vurdering av samtykkekompetanse synes ikke å være brukt i Norge (Finset 2006). Hvordan skal vi så vurdere en persons samtykkekompetanse? Selv om det er en viss enighet om at samtykkekompetanse generelt er en persons evne til å gi samtykke til helsefaglig intervensjon (undersøkelse, behandling, lindring, delta i forskning), så er det uenighet om kriteriene for å vurdere den. Videre er det en rekke praktiske utfordringer i forhold til å vurdere personers samtykkekompetanse, for eksempel om og eventuelt hvordan den lar seg måle, hvem som er kompetent til å gjøre det, og på hvilke grunnlag.

$\AA ̊$ avgjøre samtykkekompetanse involverer normative vurderinger på fem ulike nivåer: For det første må man vurdere hvilke egenskaper som er relevante for kompetansevurdering, for det andre må man bestemme konkrete kriterier for at en person skal vurderes kompetent (inklusive terskel eller konkrete krav), og for det tredje må man finne kriterier for bruk av kompetansevurderingskriteriene (når skal man vurdere kompetansen), for det fjerde må man bestemme måten man skal avgjøre kompetansevurdering, det vil for eksempel si om man skal anvende en test eller skjønn, og for det femte må man eventuelt avgjøre hvilken test man skal bruke (Faden et al. 1986).

Denne artikkelen vil primært befatte seg med nivå en og to. Hensikten er å klargjøre forutsetningene for praktisk anvendelige måter å vurdere 
samtykkekompetanse på. Det involverer grunnleggende etiske problemstillinger.

\section{Faglige eller moralske normer?}

Er ikke vurderingen av samtykkekompetanse et deskriptivt og ikke et normativ anliggende? Kan vi ikke kartlegge de kognitive eller nevrofysiologiske forhold som gjør en person samtykkekompetent? Er ikke vurdering av samtykkekompetanse således et rent helsefaglig anliggende? Standardsvaret er at samtykkeordningen har et moralsk mål: Vi innhenter personers samtykke med det formål å respektere deres selvbestemmelse (NOU 1992:8; Innst. O. nr. 91 1998-1999). Men autonomi blir definert ut fra menneskers evne til å forstå, deres frihet fra tvang og deres samtykkekompetanse (Faden et al. 1986). Kunne vi ikke ut fra undersøkelser av menneskets kognitive, sosiale eller nevrale egenskaper komme frem til objektive kriterier for samtykkekompetanse, og derigjennom autonomi?

Litteraturen antyder at dette er vanskelig (Ganzini et al. 2003; Schneider et al. 2006). Den viktigste grunnen er at det er utfordrende å implementere (kognitive eller nevrofysiologiske) tester for vurdering av om vi oppnår et moralsk mål; respekt for pasienters selvbestemmelse. ${ }^{3}$ Poenget er at dersom vi forsøker å utlede kriterier for vurdering av samtykkekompetanse ut fra kognitive eller nevrobiologiske forhold, og disse strider med allmenne oppfatninger av individers selvbestemmelse, så er de gale.

Respekt for individets selvbestemmelse er et etisk prinsipp som har fått juridisk uttrykk i pasientrettighetsloven (samtykke), og som tilsvarende trenger et (helse)faglig uttrykk i konkrete kriterier for vurdering av samtykkekompetanse, og ikke omvendt. Det dreier seg ikke om å avdekke naturgitte kriterier for samtykkekompetanse, men om normativt å begrunne dem (Schneider et al. 2006; White 1994; Berhmans et al. 2000). Validering av måleinstrumenter eller tester for samtykkekompetanse må derfor gjøres mot moralske normer. Det avgjørende for samtykkekompetansevurderinger i denne sammenhengen er hvorvidt de bidrar til å respektere personers selvbestemmelse.

Det viktige spørsmålet blir derfor hvilke grunnleggende moralske føringer som finnes i forhold til å utvikle (helse)faglig håndterbare kriterier for vurdering av samtykkekompetanse. Dersom vi utleder svaret på hva samtykkekompetanse er ut fra en vitenskapelig beskrivelse av menneskets kognitive, sosiale eller nevrobiologiske egenskaper, begår vi det som (ganske uriktig ofte) kalles «det naturalistiske mistak»; å slutte fra «er» til «bør». Jakten på samtykkekompetansens kriterier starter med spørsmålet om hvordan kompetansen bør være, for så å finne faglige normer for hvordan det 
forholder seg i praksis, gjerne gjennom empiriske studier av om de faglige normene faktisk ivaretar en persons selvbestemmelse. ${ }^{4}$

\section{Samtykkekompetanse ut fra selvbestemmelsens begrunnelse?}

Når målsettingen med samtykket er respekt for menneskers selvbestemmelse, burde vi kunne gå til selvbestemmelsens begrunnelse for å finne kriterier for å vurdere samtykke(kompetanse). Siden en autonom person må være beslutningskompetent, kunne vi finne kriterier for kompetanse ved å undersøke betingelsene for autonomi. I litteraturen gis det en rekke begrunnelser for respekt for personers selvbestemmelse, for eksempel ut fra

a. moralfilosofiske teorier (Kant 1988; Mill 1975),

b. allmenne moralske prinsipper (autonomiprinsippet)(Beauchamp et al. 2001),

c. samtykkets beskyttende effekt ved at individet bare kan underlegges inngrep som det selv har autorisert (O’Neill 2002),

d. et velferdsperspektiv, der den allmenne velferd i samfunnet øker dersom personer får beslutte selv,

e. grunnleggende menneskelige rettigheter,

f. en individuell forbrukerideologi.

I den norske helselovgivingen begrunnes samtykket ut fra en allmenn rett til selv å foreta viktige beslutninger om eget liv og helse. Det henvises ofte til respekt for menneskets autonomi, integritet og verdighet (NOU 1992:8; Innst. O. nr. 91 1998-1999), eller til allmenne menneskerettigheter, men det gis ingen eksplisitt begrunnelse for dette.

Poenget er at selv om det er rimelig enighet om at man ut fra respekt for pasienters og forsøkspersoners autonomi skal innhente samtykke, og ut fra dette også vurdere samtykkekompetanse, så er det ingen enighet om hvordan en slik autonomi skal begrunnes generelt. Selv om samtykkekompetansevurdering baseres på den moralske normen om å respektere enkeltmenneskers selvbestemmelse, så er det få klare normer for samtykkekompetansevurdering i de etiske begrunnelsene for autonomi. ${ }^{5}$

Likevel er det trolig mulig å gi noen generelle føringer for hvordan vi skal vurdere samtykkekompetanse. Disse føringene kan så være relevante for å etablere faglige retningslinjer for hvordan man skal vurdere samtykkekompetanse. 


\section{Hva er en god beslutning?}

Samtykkekompetanse er en type beslutningskompetanse, og det viktigste spørsmålet er dermed: Hva er en god beslutning?. En god beslutning er ikke er avhengig av suksess: Noen ganger tar vi (det vi må erkjenne er) mindre gode beslutninger, men lykkes likevel, mens vi andre ganger tar gode beslutninger uten å lykkes. Gode beslutninger fører med andre ord ikke nødvendigvis til økt velferd. Det betyr at vi ikke kan vurdere en persons beslutningskompetanse bare ut fra om de vil sikre personens velferd. En person kan være beslutningskompetent, selv om vedkommendes beslutninger ikke er til vedkommendes «beste», og vi kan ikke vurdere en persons beslutningskompetanse bare ut fra om vedkommende har hatt suksess med sine beslutninger tidligere. Dette motbeviser en vanlig feilforestilling om samtykkekompetanse; at «[...] pasienter som ikke følger legens råd har redusert samtykkekompetanse» (Ganzini et al. 2004). Enkeltpersoners preferanser, og deres oppfatninger av suksess, kan avvike mye fra helsepersonells preferanser og oppfatninger.

\section{Krav om generell eller spesiell samtykkekompetanse?}

Et viktig spørsmål er hvorvidt en persons samtykkekompetanse skal vurderes generelt eller spesielt. En person som har en generell samtykkekompetanse, kan mangle denne evnen i forhold til spesielle beslutninger, for eksempel ved at vedkommende ikke kan bestemme seg ved valget mellom ulike behandlingsformer ved kreft. De fleste som kaller seg oppegående og samtykkekompetente, er ikke det når de er utmattede. Motsvarende kan vi ha personer som på grunn av sykdom har redusert sin generelle samtykkekompetanse, men som likevel kan være samtykkekompetente i forhold til spesielle inngrep. Hva er viktigst i forhold til å begrunne en vurdering av personers samtykkekompetanse - det generelle eller det spesielle?

Ofte vurderer vi andre menneskers samtykkekompetanse i forhold til deres generelle evne til å ta beslutninger: Dersom en person er i stand til å ta beslutninger om seg selv i dagliglivet, så er det rimelig å anta at vedkommende klarer det også med hensyn på medisinske spørsmål. Likevel finnes det gode argumenter for at krav om spesiell samtykkekompetanse bør ha forrang fremfor generell samtykkekompetanse. Det mest åpenbare argumentet er at beslutningen om å gi samtykke gjelder en bestemt undersøkelse eller prosedyre, og at kompetansen bør vurderes i forhold til denne. ${ }^{6}$ Med dette unngår man vanskelige spørsmål med hensyn på om det finnes en slik generell samtykkekompetanse, og hva den eventuelt består i. Men det reiser spørsmål om hva det er ved en enkeltsituasjon som gjør at krav til samtykkekompetansen varierer. Mens det er forholdsvis klart at krav til for- 
ståelse (og grad av frivillighet) er avhengig av konteksten, er det ikke like åpenbart at samtykkekompetansen er det. ${ }^{?}$

Ett viktig argument for at samtykkekompetansen bør vurderes spesielt, er at det vil resultere i flere situasjoner der mennesker utøver selvbestemmelse: Den demente, som ikke har generell samtykkekompetanse, vil likevel kunne bestemme over spesielle forhold (der vedkommende er samtykkekompetent). Kontekstuell samtykkekompetanse vil således støtte opp om en intensjon om mest mulig utøvelse av selvbestemmelse. Utfordringen ved å gjøre konkrete samtykkekompetansevurderinger er å ha gode tester eller vurderingsprosedyrer for alle tenkelige situasjoner, og faren med å gjøre konkrete vurderinger er at man kan vurdere folk som kompetente i enkeltsituasjoner ut fra at de har forstått situasjonen ${ }^{8}$ eller har spesifikke preferanser, men ikke fordi de er samtykkekompetente. ${ }^{9}$

\section{Endres samtykkekompetanse gradvis eller i steg?}

For den som skal avgjøre om en person har samtykkekompetanse (i forhold til en konkret helsetjeneste), er det viktig å avklare kompetansens variasjon: Er en person enten samtykkekompetent eller ikke, eller kan samtykkekompetansen variere (slik som forståelse og frivillighet)? Dersom samtykkekompetansen varierer, er det relevant å spørre hvor man skal trekke grensen for om en person er i stand til å gi et samtykke, og hva det er som avgjør hvor denne grensen skal gå (Cale 1999). Hvis samtykkekompetansen er binær (enten/eller), unngår vi noen av disse vanskene, men tar det tilstrekkelig hensyn til variasjon i kontekst? Er kompentasen uavhengig av risikoen forbundet med en prosedyre, hvor sammensatt situasjonen er, og hvilken nytte pasienten har (sett i forhold til risiko)? Dersom det finnes en grense, hvor skal vi sette den, og hva avgjør hvor vi setter den?

Mange ser det slik at samtykkekompetansen varierer kontinuerlig - vi kan være mer eller mindre stresset, eller ha mer eller mindre overskudd eller oversikt over situasjonen. Likevel vil det som er avgjørende for vurderingen av samtykkekompetanse, være om en person har kompetanse over et gitt nivå for å samtykke til et gitt inngrep. Spørsmålet blir dermed hva det er som avgjør hvor grensen for samtykkekompetanse skal settes i forhold til et konkret inngrep.

\section{Varierer kravene til kompetanse med risiko og nytte?}

Skal vi stille samme krav til samtykkekompetanse når vi vurderer operasjon av en omfangsrik kreftsvulst som når vi vurderer å fjerne en betent negl? Må kravene til samtykkekompetanse være høyere dersom sannsynligheten for 
suksess er liten og risikoen stor? Spørsmålet er altså om krav til beslutningskompetanse skal variere med antatte konsekvenser, både når det gjelder nytte og risiko (Cale 1999).

Omfang og varighet har for eksempel betydning i forhold til beslutninger om helsehjelp i norsk lovgiving (pasientrettighetsloven, $\$ 4-6$, 1. ledd), men bare i forhold til pasienter som allerede er vurdert som inkompetente med hensyn på samtykke: «Dersom en myndig pasient ikke har samtykkekompetanse, kan den som yter helsehjelp ta avgjørelse om helsehjelp som er av lite inngripende karakter med hensyn til omfang og varighet.» Varierende krav til samtykke er også drøftet i forarbeidene til helsepersonelloven: «Kravet til samtykkets innhold vil variere etter tiltakets alvor, risiko og situasjonen forøvrig.» (Ot.prp. nr. 13, 1998-1999). Dette betyr at det ved mindre inngripende tiltak kan benyttes samtykkeformer som stilltiende samtykke eller antatt samtykke. I St.meld. nr. 50 (1993-1994) ble det foreslått å lovfeste et krav til særskilt samtykke fra pasienten før det settes i gang behandling som har spesiell risiko, eller er særlig langvarig eller smertefull. Samtidig gis det kontekstuelle formkrav: «Samtykke til helsehjelp som kan være forbundet med alvorlige komplikasjoner kan kreve større gjennomtenking og vurdering fra pasientens side enn mindre byrdefull og omfattende helsehjelp.» Dersom det er tvil om en persons samtykkekompetanse, skal også tvilen komme personen til gode. Det betyr at det stilles andre krav til samtykkets form og innhold dersom det gjelder inngrep av særlig alvorlig art, men det er ikke gitt at dette gjelder selve kompetansevurderingen.

Mange hevder at det bør stilles strengere krav til samtykkekompetanse dersom konsekvensene avviker fra hva helsepersonell faglig vurderer som rimelig. Dersom en pasient vil ta en urimelig stor sjanse for et minimalt utbytte, eller ikke ønsker å la seg operere når utsiktene er svært gode, så bør man stille strengere krav. Problemet med å variere krav til samtykkekompetanse med antatt konsekvens, er at det kan stride mot grunnintensjonen med samtykket; respekt for pasienters autonomi. Man kan hevde at pasienten selv kjenner sine verdier og derfor best er i stand til å beslutte om eget liv og egen helse, også når risikoen er stor eller utbyttet lite. ${ }^{10}$

På den annen side er det gode grunner til å hevde at det som endrer seg med konsekvensene, er kravene til vurderingen av samtykkekompetanse, og ikke kravene til samtykkekompetanse som sådan. Dersom en pasient ønsker å gjennomføre en behandling som medfører stor risiko, er det viktigere at vi er sikre på at vår vurdering av samtykkekompetansen er korrekt, enn om vedkommende skal ha fjernet en negl i forbindelse med en betennelse. Det er altså en forskjell på å endre kriteriene for samtykkekompetanse med antatt konsekvens og å endre kravene til at kriteriene er oppfylt. Ved alvorligere konsekvenser må vi være sikrere på samtykkevurderingen.

Selv om det intuitivt oppfattes som rimelig å variere krav til samtykkekompetanse med risiko og nytte, kan det undergrave muligheten for selv- 
bestemmelse og åpne for paternalisme. Dersom målet med samtykket er respekt for autonomi, kan man hevde at samtykkekravet må være det samme, men at kravet til påliteligheten til samtykkevurderingen kan variere med risiko og nytte. Dessuten kan selvsagt kravene til frivillighet og forståelse variere med risiko og nytte.

\section{Varierer kravene med hensyn på sakens kompleksitet?}

Hva gjelder dersom situasjonen er svært kompleks og vanskelig å forstå? Skal kriteriene for vurdering av samtykkekompetanse variere med sakens kompleksitet? Igjen kan man hevde at vi må være sikrere på vedkommendes kompetanse ved komplekse saker enn ved enkle inngrep.

Samtidig er det viktig å merke seg at det synes å være en forskjell mellom samtykkekompetanse og forståelse av situasjonen. En person kan tenkes å ha full forståelse for situasjonen, uten å være samtykkekompetent, som for eksempel pasienten som forstår valget mellom to behandlingsformer, men som ikke klarer å bestemme seg. Tilsvarende kan en person være samtykkekompetent (generelt) uten å ha forståelse i forhold til et gitt inngrep, for eksempel dersom vedkommende mangler viktig informasjon. Som vi skal se senere, kan det argumenteres for at det er evnen til å forstå og ikke forståelse for den konkrete situasjonen som er avgjørende for samtykkekompetansen.

Poenget her er at på samme måte som det ikke er hensiktsmessig å variere kriteriene for vurdering av samtykkekompetanse med risiko og nytte, kan det være uheldig å variere dem med sakens kompleksitet. Man kan havne i situasjoner der pasienten tar valg som man ikke er enige i, og der man kan bruke sakens kompleksitet for å hevde at vedkommende ikke er samtykkekomtetent. Ett spørsmål er imidlertid om det ikke kreves større forstålsesevne i komplekse situasjoner, og derved større samtykkekompetanse, enn i enkle situasjoner. Det kan det gjøre, men utfordringene med dette, både praktisk og etisk, blir svært store, fordi man med graduelle krav til samtykkekompetanse må angi grenser for hver enkelt situasjonstype.

\section{Akseptere vs. nekte behandling}

Et annet moralsk relevant spørsmål når det gjelder samtykkekompetansevurdering, er hvorvidt det betyr noe om personen aksepterer eller nekter tilbudt helsetiltak. I det siste tilfellet kan det bli aktuelt med tvang. Bør vi ha strengere kriterier for personer som nekter helsetiltak som ansees som nødvendige av helsepersonell, og der det kan bli aktuelt med tvangsbehandling, enn for personer som takker ja til slike tiltak? Det er et slikt skille i norsk helselovgiving i dag; helsehjelp som ansees som påtrengende nødvendig, 
kan gis uten personers samtykke. ${ }^{11}$ Det kan hevdes at det er praktiske og ikke prinsipielle grunner til dette: Man kan ikke bruke tid på lange prosedyrer og overveielser med hensyn på samtykkekompetanse når det står om liv.

Det moralsk relevante og utfordrende er derimot at en person som ikke samtykker til behandling som oppfattes som (påtrengende) nødvendig, underlegges grundig kompetansevurdering, men en person som sier ja, ikke gjør det. En asymmetrisk vurdering av samtykkekompetanse kan stride mot intensjonene med samtykkeordningen.

\section{Forståelse for den konkrete beslutning eller forståelsesevne generelt?}

Selv om forståelse verken synes å være en nødvendig eller tilstrekkelig betingelse for å ha samtykkekompetanse, er det av betydning for samtykkekompetansevurderingen. For å fatte en beslutning om noe som er av betydning for ens liv, må man ha forstått hva beslutningen omfatter. Men når vi vurderer om en person er samtykkekompetent, er det evnen til å fatte beslutninger som vurderes. At personen har forstått den konkrete situasjonen, kommer som et eget kriterium (i tillegg til frivillighet og samtykkekompetanse) for at et samtykke skal kunne være et gyldig. ${ }^{12}$

For å ha evnen til å fatte beslutninger må man altså ha evnen til å forstå hva beslutningen omfatter. Forskjellen på forståelse og forståelsesevne som kriterium for samtykkekompetanse kan virke teoretisk og praksisfjernt: Når man skal vurdere beslutningskompetanse i en konkret situasjon, vil man vurdere om vedkommende har forstått situasjonen, og har vedkommende forstått den, så har vedkommende også forståelsesevne. Men man kan være samtykkekompetent uten å ha forstått detaljene i en forestående behandling, slik at det er forståelsesevne, og ikke forståelse, som er en nødvendig betingelse for samtykkekompetanse. Dessuten kan det forhindre utilsiktede virkninger: En person kan vurderes som ikke samtykkekompetent fordi vedkommende ikke har forstått en gitt situasjon, for eksempel fordi han eller hun har fått for lite informasjon, har fått informasjonen på en lite tilpasset måte, eller fordi vedkommendes beslutninger ifølge helsepersonell er urimelige.

Det kan altså være mange grunner til at en person ikke har forstått en situasjon, og det gjør det viktig å skille mellom forståelse og forståelsesevne. Det kan for eksempel være kulturelle forskjeller mellom den som forklarer, og den som forsøker å forstå, og det gjør at personen ikke forstår selv om forklaringen kan være god. Faren er at personer blir stemplet som ikkesamtykkekompetente dersom de ikke forstår. En person som har hatt hjer- 
neslag, kan være samtykkekompetent (og ha forståelsesevne), selv om måten forståelsen erverves på har endret seg drastisk med slaget. ${ }^{13}$

Dersom det er et moralsk relevant skille mellom forståelsesevne og forståelse for vurdering av beslutningskompetanse, reises spørsmålet om man må vurdere forståelsesevnen (og dermed deler av beslutningskompetansen) generelt, og ikke i forhold til den konkrete situasjonen. Men en person som mangler forståelse for en konkret situasjon, mangler ikke nødvendigvis samtykkekompetanse: Selv om forståelse er en nødvendig betingelse for et gyldig samtykke, er forståelse verken et nødvendig eller tilstrekkelig kriterium for beslutningskompetanse, og det kan ha alvorlige moralske implikasjoner å overse dette. ${ }^{14}$

\section{Kognitiv eller emosjonell kompetanse?}

Et annet viktig spørsmål er om samtykkekompetanse baserer seg på en persons rasjonelle egenskaper, eller om den også omfatter personens emosjonelle evner. Vi kan tenke oss en person som rasjonelt sett forstår sin egen situasjon og hvilke alternativer som foreligger, men der følelsene tar overhånd og gjør at han tar beslutninger som strider mot hans rasjonelle overveielser. Er personen samtykkekompetent? Dersom vedkommende ikke er det, må vi tilkjenne emosjonene en rolle i kompetansevurderingen. Hva med en person som virker fullstendig rasjonell, men som mangler emosjonelt engasjement - er vedkommende samtykkekompetent? Personer som kaldt og nøytralt gjør rede for at de har forstått, men som ikke viser noe engasjement, får oss til å undres om dette virkelig er en beslutning som vedkommende står inne for - om vedkommende er samtykkekompetent.

Kognitive kriterier for vurdering av samtykkekompetanse omfatter at vi er i stand til å lage og følge en plan, at vi klarer å vurdere og rangere alternativer, har evne til å gjøre et valg og å stå ved valget over tid. Dersom vi klarer dette, synes vi kognitivt sett å være i stand til å bestemme i spørsmål om helse. Hva med krav til emosjonelle evner? Det er mange emosjoner involvert i beslutningsprosesser, men bare noen få er relevante for å vurdere kompetanse. Motivasjon er avgjørende for samtykkekompetanse. Dersom en person er likegyldig, eller ikke klarer å relatere situasjonen til seg selv, selv om vedkommende sier ja til behandling, er vedkommende antagelig ikke samtykkekompetent. Når en person med lammelse i armer og ben ser sin situasjon som håpløs, sier at livet har mistet sin mening og er likegyldig til hva som skjer med ham, sier ja til en eksperimentell behandling, er det tvilsomt om vedkommendes samtykke er gyldig, fordi vedkommende kanskje ikke er samtykkekompetent. Det betyr at vurderingen av samtykkekompetanse også inneholder emosjonelle komponenter, og at evne til å relatere handlingsalternativer til seg selv, er en av dem. 


\section{Evnen til å avveie alternativer}

For å ta beslutninger om eget liv og egen helse er det også viktig at en kan vurdere og rangere alternativer og fatte en beslutning. Det holder ikke at en person kan forstå all relevant informasjon, og at vedkommende klarer å se at dette er relevant for en selv, dersom en ikke klarer å vurdere handlingsalternativer og rangere dem i henhold til egne verdier. En pasient som har valget mellom stråleterapi og kjemoterapi, men som ikke klarer å vurdere alternativene i forhold til egne verdier, er ikke samtykkekompetent, selv om vedkommende har den mest inngående kunnskap om handlingsalternativene.

Mange hevder at evnen til å være konsistent og koherent er sentral i vurderingen av samtykkekompetanse. Utfordringen med dette er at å vurdere en persons konsistens (i moralsk og ikke i logisk forstand) vil kreve at den som vurderer, må ha oversikt over personens drivkrefter og verdier, og i en viss forstand påberoper seg å vite hva som er «best» for personen. Det er åpenbart problematisk. Dersom skifte av preferanser og endring av beslutninger diskvalifiserer for samtykkekompetanse, så reduserer det samtidig antall personer som er samtykkekompetente.

\section{Evnen til å gi uttrykk for en beslutning}

Et annet vesentlig kriterium for at en person skal være beslutningskompetent, er at vedkommende er i stand til å gi uttrykk for sine valg. Det er viktig for at vedkommende skal kunne uttrykke sitt samtykke, men også i forhold til samtykkekompetansen. En person som har klare oppfatninger om hva vedkommende vil, men som ikke kan uttrykke et valg, er ikke samtykkekompetent. Enkelte mennesker kan gi tydelig uttrykk for entydige valg blant familie og venner, men når de skal uttrykke seg overfor helsepersonell, er det motsatt. ${ }^{15}$ For å være sikker på at samtykket er uttrykk for personens selvbestemmelse, bør evnen til å gi uttrykk for et valg være en betingelse for samtykkekompetanse.

Må en person kunne begrunne sine beslutninger? For å ta rede på personens evne til å vurdere og rangere handlingsvalg er det enklest å vurdere vedkommendes begrunnelser. Utfordringen med dette er at vedkommende kan gi begrunnelser (ut fra sine verdibaserte avveiinger) som vi vil oppfatte som inadekvate. Vi kan derfor komme til å vurdere en person som ikke samtykkekompetent fordi vedkommende gjør andre avveiinger enn vi synes er rimelige. Dette er uheldig fordi det kan være en rekke situasjoner der pasienten ikke trenger å gjøre rede for sine valg. Eksempelvis er en person som kan donere en nyre til sin syke datter, men som ikke vil gjøre det, ikke pliktig til å gi noen grunner for sitt valg. Dersom vedkommende gir 
grunner som vi ikke aksepterer, så betyr ikke det at personen ikke er samtykkekompetent (og langt mindre at vi kan ta vedkommendes nyre).

\section{Avslutning}

Denne artikkelen har forsøkt å undersøke en del moralske føringer for hvordan man bør vurdere samtykkekompetanse dersom målsettingen er å respektere personers selvbestemmelse. Selv om jeg også har berørt den moralske bakgrunnen for samtykkeordningen (selvbestemmelse), så har det normative grunnlaget for utformingen av dens praksis vært mitt hovedanliggende. Den viktigste moralske utfordringen er å forhindre at samtykkekompetansevurderinger generelt, og kriteriene for slike vurderinger spesielt, bidrar til det motsatte av hva man ønsker å oppnå: respekt for personers selvbestemmelse. Det kan skje dersom samtykkekompetansevurdering avhenger av i hvilken grad en persons beslutninger strider mot helsepersonells oppfatning av hva som er «til beste for pasienten», eller dersom vi oppfatter pasienten som ikke samtykkekompetent fordi vedkommende ikke forstår viktig informasjon om et helsetiltak.

Jeg har forsøkt å vise at forsøk på å forankre samtykkekompetansevurderinger direkte i kognitive eller nevrologiske forhold vil være å slutte fra «er» til «bør», og at man her må klarlegge de moralske forhold for eventuelt å finne tester som gjenspeiler disse. Satt på spissen: Man må slutte fra «bør» til «er». Tilsvarende er det vanskelig å finne kriterier for vurdering av samtykkekompetanse i de teoriene som begrunner samtykkeordningen (selvbestemmelse).

Jeg har forsøkt å vise at en persons beslutningskompetanse ikke avhenger av en persons evne til å fatte gode beslutninger, og at samtykkekompetanse i praksis bør vurderes i forhold til konkrete beslutninger. Det finnes gode argumenter for at samtykkekompetansen er stegvis og ikke graduell, slik som andre samtykkekrav (f.eks. forståelse og frivillighet). Videre bør kravene til vurderingens pålitelighet variere med risiko og nytte, men det bør ikke kravene til samtykkekompetanse. Det samme gjelder sakens kompleksitet: Komplekse situasjoner stiller større krav til forståelse, men ikke til samtykkekompetanse. Det er heller ingen asymmetri med hensyn på positive og negative beslutninger: Samme kriterier for samtykkekompetanse gjelder om en person sier ja eller nei (til undersøkelse eller behandling).

Ut over dette er evnen til å avveie alternativer og evnen til å gi uttrykk for beslutninger, viktige elementer i en persons samtykkekompetanse, uten at personen nødvendigvis må gi grunner for sine beslutninger.

Samtykkekompetanse må dessuten ikke bare vurderes ut fra kognitive kriterier. Emosjonelle evner, som motivasjon og evnen til å relatere informasjon til en selv og ens liv, er viktige for samtykkekompetansen. 
Det finnes altså en rekke moralske føringer for vurderingen av samtykkekompetanse dersom samtykket skal oppnå målsettingen om å respektere personers selvbestemmelse, slik det ofte blir hevdet. Dersom samtykket skal ha en annen hensikt, endres selvsagt argumentasjonen. ${ }^{16}$

Poenget her er at enten vi ønsker å utvikle eller ta i bruk standardiserte tester eller prosedyrer for å vurdere samtykkekompetanse i Norge, eller om vi vil basere slike vurderinger på skjønn, så vil uansett slike moralske føringer som er drøftet i denne artikkelen, være avgjørende for hvordan det gjøres i praksis.

\section{Litteratur}

Appelbaum, P. S. \& Grisso, T. (2001) MacArthur competence assessment tool for clinical research (MacCAT-CR). Sarasota, Florida Professional Resource Press.

Berghmans, R. L. P. \& Wideershoven, G. A. M. (2000) Ethical perspectives on decision-making capacity and consent for treatment and research. Medicine and Law, 22, s. 391-400.

Beuchamp, T. L. \& Childress, J. F. (2001) Principles of biomedical ethics. New York: Oxford University Press.

Cale, G. S. (1999) Risk-related standards of competence: continuing the debate over risk-related standards of competence. Bioethics, 13, s. 131-148.

Dixon-Woods, M., Williams, S. J., Jackson, C. J., Akkad, A., Kenyon, S. \& Habiba, M. (2006) Why do women consent to surgery, even when they do not want to? An interactionist and Bourdieusian analysis. Social Science and Medicine, 62, s. 2742-2753.

Etchells, E., Sharpe, G., Elliot, C. \& Singer, P. A. (1996) Bioethics for clinicians: 3. Capacity. Canadian Medical Association Journal, 155, s. 657-661.

Faden, R. \& Beauchamp, T. (1986) A history and theory of informed consent. New York: Oxford University Press, s. 238.

Finset, A. (2006) personlig meddelelse 23.09.2006 i forbindelse med seminaret «Hvordan vurderer vi pasienter og forsøkspersoners samtykkekompetanse» ved Seksjon for medisinsk etikk.

Ganzini, L., Volicer, L., Nelson, W. \& Derse, A. (2003) Pitfalls in assessment of decision-making capacity. Psycomsomatics, 33, s. 237-243.

Ganzini, L., Volicer, L., Nelson, W. A., Fox, E. \& Derse, A. R. (2004) Ten myths about decision-making capacity. Journal of the American Medical Directors Association, 5, s. 263-267.

Glass, K. C. (1997) Refining definitions and devising instruments: two decades of assessing mental competence. International Journal of Law and Psychiatry, 20, s. $5-33$.

Howe, V., Foister, K., Jenkins, K., Keks, N., Skene, L. \& Copolov, D. (2003) Competence to Give Informed Consent to Research Participation in Persons with Schizophrenia and Related Psychosis. Psychiatry, Psychology and Law, 10, s. 85-90.

Kant, I. (1988) Grundlegung zur Metaphysik der Sitten. Stuttgart: Reclam.

Mill, J. S. (1975) On liberty. London: Penguin Books. 
Moye, J. (1999) Assessment of competency and decision making capacity. I Handbook of assessment in clinical gerontology, red. P. A. Lichetenberg, s. 488-528. New York: John Wiley \& Sons, Inc.

Norge, Stortinget, Innst. O. nr.91 (1998-1999) Innstilling fra sosialkomiteen om lov om pasientrettigheter (pasientrettighetsloven).

Norge, Stortinget, St.meld. nr. 50 (1993-1994) Samarbeid og styring. Mål og virkemidler for en bedre helsetjeneste.

Norge, NOU 1992:8. (1992) Lov om pasientrettigheter.

Norge, Ot.prp. nr. 12 (1998-1999) Lov om pasientrettigheter (pasientrettighetsloven).

Norge, Ot.prp. nr. 13 (1998-1999) Lov om helsepersonell m.v. (helsepersonelloven).

Northoff, G. (2006) Neuroscience of decision making and informed consent: an investigation in neuroethics. Journal of Medical Ethics, 32, s. 70-73.

O'Neill, O. (2002) Autonomy and trust in bioethics. Cambridge: Cambridge University Press.

Schneider, P. L. \& Bramstedt, K. A. (2006) When psychiatry and bioethics disagree about patient decision making capacity (DMC). J Med Ethics, 32, s. 90-93.

Tunzi, M. (2001) Can the patient decide? Evaluating patient capacity in practice. Amican Family Physician, 64, s. 299-306.

White, B. C. (1994) Competence to consent. Washington D.C.: Georgetown University Press.

Wong, J. G., Clare, H. C., Gunn, M. J. \& Holland, A. J. (1999) Capacity to make health care decisions: its importance in clinical practice. Psychological Medicine, 29, s. 437-446.

\section{Noter}

1 Det er ikke uproblematisk at helsepersonell i tillegg til helsefaglige vurderinger skal vurdere personers samtykkekompetanse i forhold til helsefaglige intervensjoner. Får de ikke da en dobbeltrolle? Er helsepersonell spesielt egnet til å vurdere samtykkekompetanse? Dette er viktige og vanskelige spørsmål, som dessverre faller utenfor rammen av denne artikkelen.

2 Hvis det er tvil om samtykkekompetansen, skal den ifølge forarbeidene til pasientrettighetsloven komme pasienten til gode.

3 Det er viktig å merke seg at jeg her tar utgangspunkt i det som er grunnlaget og begrunnelsen for samtykkeordningen i norsk helselovgiving. Samtykket kan selvsagt forsvares på en rekke andre måter. Dersom samtykket ikke begrunnes ut fra respekten for individets selvbestemmelse, vil flere av argumentene i denne artikkelen falle bort eller endres.

4 Når kriteriene for samtykkekompetansevurderinger er på plass, er det et deskriptivt spørsmål hvorvidt en konkret person eller pasient er samtykkekompetent. I denne artikkelen dreier det seg om hvordan kriteriene skal utformes. Mens anvendelsen av kriteriene kan være rent deskriptiv, er kriteriene for utviklingen og valideringen av kriteriene normative.

5 Man kan hevde at Gerald Dworkins autentisitetsteori for autonomi kan legge føringer for samtykkekompetansevurderinger fordi samtykkekompetansen kan sies å være karakterisert av en persons evne til å veie sine førsteordens preferanser i for- 
hold til sine andreordens preferanser. Tilsvarende kan man utlede føringer for kompetansevurderinger fra Kants og Mills filosofi uten få entydige kriterier for samtykkevurderinger.

6 Klassiske eksempler er den demente personen som er samtykkekompetent i forhold til å bestemme kosthold, men som ikke er det i forhold til beslutninger om medisinsk behandling og deltagelse i forskningsprosjekt, eller alkoholikeren som er samtykkekompetent i forhold til et konkret operativt inngrep, men som ikke er det i forhold til beslutninger relatert til alkohol.

7 I forhold til alkoholikerens beslutninger relatert til alkohol, kan det argumenteres for at det som gjør vedkommendes samtykke ugyldig, er både manglende frivillighet og manglende samtykkekompetanse.

8 Eksempler på at man har forstått situasjonen uten å ha samtykkekompetanse, kan være når man er godt informert om en operasjon som man tidligere har samtykket til, og like før operasjonen nekter, eller når man er godt informert og har forstått alle detaljer ved en forestående risikabel og smertefull behandling, men ikke klarer å knytte behandlingen til en selv eller ikke klarer å bestemme seg for om man vil gjennomføre den.

9 Kontekstuell samtykkekompetanse skaper utfordringer for generelle tester av samtykkekompetanse: Vi kan ikke ha egne tester for enhver situasjon. Å teste samtykkekompetansen med generelle tester behøver ikke å eliminere muligheten av å vurdere den kontekstuelt. Man kan for eksempel hevde at den generelle testen kan utføres i alle situasjoner, men at resultatet må vurderes i forhold til den enkelte situasjon. Man må stille større krav i situasjoner der risikoen er stor og nytten liten, men som vi skal se senere, er dette ikke uproblematisk.

10 Problemet her er at man skal vurdere hvorvidt personen er i stand til selv å vurdere hva som er til vedkommendes «beste».

11 Hjelpeplikten i helsepersonelloven $₫ 7$, med tre unntak gitt i pasientrettighetsloven $\$ 3-9$ : sultestreikende, døende og personer som av alvorlig overbevisning ikke ønsker å få overført blod.

12 Med gyldig samtykke mener jeg her et samtykke som er gitt av en person som er i stand til å fatte autonome beslutninger.

13 Psykologiske tester vurderer beslutningskompetanse generelt (og ikke spesielt i forhold til en konkret situasjon). Dette synes å utfordre påstandene om at samtykkekompetansen bør vurderes i forhold til den konkrete situasjoner. En mulig løsning er at forståelsesevnen kan vurderes ut fra beslutningens omfang, men ikke spesifikt i forhold til konkrete enkeltbeslutninger: «Denne personen er kompetent til å samtykke til behandlinger av typen $\mathrm{X}$, men ikke av typen $\mathrm{Y}$ » osv.

14 For å vurdere en persons forståelsesevne må en vurdere en rekke konkrete egenskaper, som hukommelse og evnen til å meddele valg. Andre evner som ofte knyttes til samtykkekompetanse, er evne til å resonnere og fatte en beslutning. I denne artikkelen berøres bare de som har direkte relevans for den moralske målsettingen; å respektere personers selvbestemmelse.

15 Det er kjent at mange samtykker selv om de ikke vil (Dixon-Woods et al. 2006). Ofte skyldes dette forventinger, sosialt press eller ufrihet, og ikke manglende samtykkekompetanse. Mangel på samtykkekompetanse er det derimot dersom man ikke klarer å gi uttrykk for sin beslutning, selv om man ikke utsettes for press. En person som lider av genuin beslutningsvegring, kan ikke være samtykkekompetent.

16 Det er ikke vanskelig å se at det finnes sterke motsetninger mellom kravene til samtykkekompetanse som kommer frem i denne artikkelen, og at det i seg selv kan brukes til å avvise at respekten for pasienters selvbestemmelse kan brukes til å begrunne krav til samtykkekompetanse eller samtykket som sådan. Poenget her har vært å un- 
dersøke hvordan samtykkekompetansekriteriene bør være dersom de skal begrunnes ut fra selvbestemmelsen og unngå å undergrave den. 